\title{
Impact of Bancassurance on Financial Performance of Private Commercial Banks in India
}

\section{Ansuman Samal}

\begin{abstract}
In order to get competitive advantage, many Financial Institutions are sharing resources in the current scenario. To ward off competition Financial Institutions have tied up with the banks which is termed as bancassurance. The present study is focused on studying the impact of bancassurance on the financial performance of the privately owned commercial banks in India full stop the data was collected from 180 respondents working in 6 private banks of India. With the help of a questionnaire the primary data is collected and the secondary data was collected from the respective Bank sites. It was found that banks should come up with optimum optimal regulatory policies that won't allow them to compromise with the banks performance. And they have to recruit the best management talents so that right decision, smooth handling of the risk can be done by the banks.
\end{abstract}

Keywords:Bancassurance,CapitalAdequacy,AssetQuality,Man agementQuality

\section{INTRODUCTION}

According to Kasper 2005 Bancassurance is emerge particularly due to the emerging markets. Throughout the world insurance companies are trying to use the channels of distribution of banks in order to leverage profits in the new markets. In Europe there is penetration rate of Bancassurance but in American and African markets the penetration is very low the bank insurance is gaining lot of popularity in Asian markets especially in China. Though Bancassurance remains to be a very positive way of distribution but it is dependent on the countries Regulation and business environment. Though in Asian markets Bancassurance seems to be catching up a lot but in India it is still has to go a long way in order to achieve the optimum advantage of the tie up.Bancassuranceas a way of financialassortmenthas appealed widespreadattention in the world of researchersand businesssinceitoffersconsumersan instant optionfora largerrangeof fiscal product (Voutilainen, 2006).

From 1991 onwards banassurance had been a contemporary way to sell insurance products through the banks rather than directly contacting a customer. There are a few reasons why banks think about bancassurance, the most imperative of which is expanded Return on Assets (ROA). A standout amongst the most ideal approaches to expand ROA, accepting a steady resource base, is through charge pay which is work through the closeout of protection items. Banks can likewise use their dissemination and handling capacities for productive working cost proportions. By utilizing their qualities and discovering approaches to conquer their shortcomings, banks could change the substance of protection dispersion. Clearance of individual disaster protection items through banks meets an essential arrangement of purchaser needs. Most vast retail banks induce a lot of trust in expansive fragments of purchasers, which they can use in offering them individual life coverage items. Also, a bank's office arrange enables the eye to eye contact that is so vital in the closeout of individual protection. Moreover, have solid market mindfulness, set up conveyance channels and appreciate a more extensive territorial inclusion. As per Kumar (2006), the most ideal approach to break down the significance of protection charge salary of a bank is to quantify it against the premium edges. For instance, protection on vast and convoluted ventures can bring a generous charge salary as protection premiums. Therefore, the charge salary can be utilized to halfway counterbalance the intrigue decrease in a focused loaning condition. Bancassurance additionally improves a bank's budget report things through maintenance of clients. As indicated by Kumar (2006), a bank selling a multi year yearly speculation ties the client with the bank for the following ten years. This gives the bank an incredible chance to expand on potential extra business with the customer. The present investigation thusly looked to build up the impact of bancassurance on money related execution of business banks.

Banks in India for quite a while have been pondering the lessening to their greatest advantage edges because of the ascent in rivalry, changes in innovation, deregulation of the money related segment just as globalization. The real pay created by banks is premium salary, anyway current economic situations have put a strain on the premium pay as expense of getting reserves have generously risen and loaning has turned out to be too focused to even think about providing advantageous premium pay. With the appearance of versatile cash exchange, banks have seen a drop in the store base of their clients. Also, new and imaginative items in the media communications industry have enabled clients to get credits through their cell phones. In this manner with the need to differentiate tasks, change in accordance with the adjustments in client needs and adventure into new and gainful markets banks have needed to wander into bancassurance so as to keep up to keep up their gainfulness and furthermore survival in the consistently changing business world. Bancassurance has been an effective model 
in European nations contributing $35 \%$ of premium salary in the European life coverage showcase. It contributes over $65 \%$ of the disaster protection premium salary in Spain, $60 \%$ in France, half in Belgium and Italy. There is incredible potential for development of bancassurance in India and in spite of the numerous advantages of bancassurance the present take-up of bancassurance is still moderately low. Besides, bancassurance would not just balance out the financial area with extra income streams yet would likewise advance client maintenance, upgrade exceed and enhance activities. At last, fruitful execution would not exclusively be valuable to business banks yet the stream impact will be felt from a client point of view with lower premium which thus would cultivate financial improvement. Concentrates recently done in India on the connection among bancassurance and the monetary execution of Indian business banks have demonstrated differing results. The present examination in this way looked to set up the impact of bancassurance on money related execution.

\section{OBJECTIVES OF THESTUDY}

The general objective of the study was to establish the influence of bancassurance on financial performance of private commercial banks in Bhubaneswar,India. The study intends to evaluate the influence of capital adequacy, management quality, liquidity and asset quality on financial performance of commercial banks.

\section{REVIEW OF LITERATURE}

\section{Influence of Capital Adequacy on Financial Performance}

According to Olalekan and Adeyinka (2013), adequate capital is regarded as the amount of capital that can effectively discharge the primary capital function of preventing bank failure by absorbing losses. Adequate capital provides the ultimate protection against insolvency and liquidation arising from the risk in the banking business. Any bank with inadequate capital faces hidden constraints. Its management time is spent on the defensive, working out how to raise capital or how to guard against takeovers. Due to the debt-like nature of liabilities in banks, they have an incentive to engage in risk-shifting or asset substitution. This means that they will indulge in high-risk activities to shift the downside- risk to creditors. To avoid this, regulators require them to hold a minimum ratio of capital to assets to reduce their sensitivity to risk (Kongiri, 2012). In this case, capital adequacy can be measured using ratios such as capital to liabilities and the capital to assets ratio. Earlier studies on capital adequacy as a determinant of profitability of banks revealed that a high capital adequacy ratio should signify a bank that is operating over-cautiously and ignoring potentially profitable trading opportunities (Goddard et al., 2004), which implies a negative relationship between equity to asset ratio and bank performance. Adequate capital for banks is the level at which the deposit insurance agency would breakeven in guaranteeing the deposits of individual banks with premium the banks pay. Various studies suggest that banks with higher levels of capital perform better than their undercapitalized peers. Staikouras and Wood (2003) claimed that there exists a positive link between greater equity and profitability among
EU banks. Goddard et al., (2004) supports the prior finding of a positive relationship between capital/asset ratio and bank's earnings. Again the direction of the relationship between bank capital and bank performance cannot be unanimously predicted in advance. It, therefore, calls for further empirical analysis to ascertain the direction for this relationship. Furthermore, from the empirical analysis, there is limited or no evidence of critical analysis of this relationship with respect to banks that have ventured into bancassurance. The current study therefore aimed at filling this empirical gap majoring on the Indian context.

\section{Influence of Asset Quality on Financial Performance}

Dissimilar to different business associations, for example, the assembling firms that stock substantial products as stock, the supply of the financial business is cash; this implies banks exchange on cash (Aruwa and Musa, 2014). By its temperament banks face number of difficulties inside interior and the outer business condition. Essentially, banks work with three fundamental goals which are gainfulness, development of benefits and client base. Resource quality involves the assessment of firm resources so as to encourage the estimation of the dimension and size of acknowledge chance related for its activity. Continuing sound resources quality includes watchful giving of advances that must be analyzed and consistence to banking rules. Resource quality is a proportion of the likelihood that the credit will either be paid or not. It is estimated utilizing credit hazard which is the danger of misfortune due to non-installment of indebted individuals' advances (Ogilo, 2012). The disappointment of an account holder to pay an advance improves the credit danger of a bank and in this manner lessens its benefit quality. Kongiri (2012) noticed that advantage quality is estimated by the proportion of net non-performing advances to the gross advances. Moreover, Molyneux et al., (2007) noticed that the different pointers to the decay in the benefit esteem could be through utilizing proportions, for example, profit resources for absolute resources and the provisioning of gross development proportions. Different examinations universally and locally have endeavored to clarify the connection between resource quality and bank execution. For instance, Abata (2014) inspected resources quality and bank execution of six biggest banks cited in Nigeria stock trade and uncovered that advantages quality impacts bank execution. Likewise, Vighneswara (2015) analyzed the determinants of bank resource quality and productivity in India utilizing board information systems from the period from 1997 - 2009. The discoveries uncover that capital ampleness and speculation action altogether influence the productivity of business banks. Locally, Musyoki and Kadubo (2011) additionally discovered that credit chance administration is a critical indicator of bank's budgetary execution; they presumed that banks achievement relies upon credit chance administration and in this manner spotlight ought to be put on guaranteeing sound resource quality administration. Moreover, Kithinji (2010) investigated the impact of credit hazard the board and found 
that the main part of the benefits of business banks are not affected by the measure of credit and non performing advances. The suggestion is that different factors separated from credit and non performing advances sway on banks' benefit. It is in this manner clear that the connection between resource quality and monetary execution of banks and all the more so those which have taken up bancassurance is as yet restricted and along these lines the present examination endeavored to fill this information hole.

\section{Influence of Management Quality on Financial Performance}

Ongoing investigations have asserted that the effective execution of value the board could create improved items and administrations, just as diminished costs, progressively fulfilled clients and workers, and improved budgetary execution (Mwaniki and Okibo, 2014). The executives quality in business banks may not be effectively estimated utilizing budgetary proportions as the impacts and procedures are subjective (Ogilo, 2012). The job of the executives in banking establishments guarantees the smooth tasks of exercises, everyday treatment of dangers and the job of stewardship. The organization issue shows itself in the overseeing of monetary establishments where administrators put their own objectives first as opposed to amplifying investor esteem. Quality administration has turned into an acknowledged system to guarantee execution and survival in current economies. Deming (1995) had prior attested that the achievement of value the board endeavors relied on the powerful incorporation of different administration subsystems. It coordinates crucial administration methods, assets, and its execution remains as a test and backing to top administration. As indicated by Eriksson and Hansson (2002), the fundamental point of value the board is to execute an administration framework and authoritative culture that guarantees the consumer loyalty since clients who are increasingly touchy to quality models improve their desires consistently. Numerous examinations have demonstrated that the execution of banks is fundamentally and decidedly connected with the administration quality, and to accomplish administration quality in the financial part, quality administration is profoundly basic. Locally, Awino et al., (2012) in their examination on quality administration and upper hand of agricultural firms noticed the administration quality is one of the key segments for upgraded upper hand. Likewise, Mwaniki and Okibo (2014), in their examination on the impact of all out quality administration on the money related execution of business banks in India noticed that quality administration has turned into an acknowledged procedure to guarantee execution and survival in the advanced economies. It is subsequently reasonable to additionally analyze the relationship of the board quality and bank execution while concentrating on banks that have natured into bancassurance.

\section{Influence of Liquidity on Financial Performance}

The Reserve Bank of India (2012) characterizes liquidity as "the capacity of money related foundations to finance increments in resource property and meet commitments as they fall due". One key reason for bank supervisors is the administration of liquidity hazard which can result from a bungle in the developments of benefits and the "commitments due" for these situation withdrawable stores, and whose event in one establishment can effectively affect the entire business. With this in view bank controllers endeavor to oversee bank liquidity hazard by forcing least liquidity proportions and furthermore by utilizing fiscal strategy. In the Indian case, the statutory least liquidity proportion is $20 \%$. Banks have anyway figured out how to keep up a liquidity proportion well in abundance of the base set by the administrative experts yet as Kamau (2011) contends that there is an open door cost in holding high liquidity, which is described by loss of a chance to clutch high enthusiasm producing ventures. A few examinations have discovered a positive relationship; some found a negative relationship while others found the two outcomes and a couple of found no relationship by any means. For instance, Kosmidou et al., (2005) found that the proportion of fluid advantages for client and transient subsidizing is decidedly identified with ROA and measurably noteworthy. As of late, Olagunju et al., (2012) discovered that there is a positive noteworthy connection among liquidity and gainfulness. A few creators found blended consequences of both negative and positive relationship. Shen et al., (2010) affirm that in market-based money related framework liquidity hazard is decidedly identified with net premium edge a sign that manages an account with abnormal amounts of illiquid resources get higher premium salary. They called attention to that banks acquired higher subsidizing cost in the market in the event that they have illiquid resources as they needed to collect the cash in the market to meet the financing hole. Demirgüç-Kunt and Huizinga (1999) found uncertain outcomes; they found a positive connection between credits to add up to resources and the net intrigue edges. They additionally settled a converse connection between the net intrigue edge and before duty benefits. Altogether, bancassurance has been found to build bank liquidity and hence decisions about the impact of banks' liquidity on their gainfulness stay questionable and further research is required.

\section{RESEARCHMETHODOLOGY}

The examination utilized a spellbinding structure while utilizing quantitative methodologies. As indicated by Mugenda and Mugenda (2003), expressive examinations are typically the best techniques for gathering data that exhibit connections and portray the world as it exists. In India, there is a case by case exception surveyed by the Insurance Regulatory Authority related to Central Bank of India of business banks that offers bancassurance. For this situation, the number of inhabitants in the investigation was the six banks offering bancassurance in Bhubaneswar. The objective populace was accordingly 180 account related workers of these banks. From the objective populace of 180 workers, an example which is the genuine delegate of the populace was classified utilizing factual formulae and distributed proportionately among the private business banks. 


\section{IMPACT OF BANCASSURANCE ON FINANCIAL PERFORMANCE OF PRIVATE COMMERCIAL BANKS IN INDIA}

Straightforward arbitrary examining method was utilized in gathering information since that the example was agent, dependable, adaptable and effective. Information was gathered utilizing a nearby finished poll. The poll is viewed as suitable; it enables information to be gathered in a fast and effective way (Saunders and Lewis, 2009). Optional information for the investigation was gathered from the Central Bank of India and from yearly bank distributions. The essential information was sourced from the appropriate responses the members gave amid the study procedure. The Statistical Package for Social Sciences (SPSS) Version 21 was utilized to break down the information and the outcomes acquired were displayed utilizing tables For the motivation behind examining the connections of every one of the free factor on the reliant variable, the investigation utilized relapse examination to test the theory. In estimating the budgetary execution of banks the investigation utilized Return on Asset (ROA) as proportions of execution. Out of 125 surveys that were issued to the tested respondents, 112 of them were filled and returned. Of these, 9 were erroneously filled and consequently were not utilized in the last investigation. Along these lines, 103 surveys were effectively filled and thus were utilized for investigation speaking to a reaction rate of $82.4 \%$.

\section{RESEARCH FINDINGSAND DISCUSSIONS \& RESULTS}

The specialist tried to discover the dissemination of the respondents as indicated by their gender, age section, training level, and working background. The point was to conclude any pattern from the respondent's profile that was straightforwardly connected to the factors of the examination. As indicated by the discoveries, the dominant part of representatives was male $(55.3 \%)$ while female was $44.7 \%$. The analyst credited this pattern to the current sex hole in work in many segments in India today. Lion's share of representatives in many banks was of the age amass 31 40 years $(38.8 \%)$ while the least age assemble is underneath 21 years $(1 \%)$. The analyst credited this to the low business open doors given by private area associations in India in the previous decade. The investigation set up that over $91 \%$ of the respondents had a college degree or an ace degree dimension of instruction which was credited to the higher passage capability levels in the financial part in India. Further, just $8.7 \%$ of the respondents had a confirmation dimension of training further demonstrating higher instructive necessities expected to join the financial division in India. In conclusion, a larger part of the respondents (40.8\%) had worked for between 5 to 10 years in their particular banks. Aggregately, over $65 \%$ had over 5 years of experience while just $6.8 \%$ had under 1 year of working background. This pattern was ascribed to the way that most the Indian economy has not been making enough openings for work to expand assimilation of new representatives. Further, the more extended experience suggested that most representatives plainly know the functions of their banks and along these lines, their reactions would be substantial and essential.

\section{Influence of Capital Adequacy on Financial Performance}

The study sought to establish the influence of capital adequacy on financial performance of banks and the results of the analys is are shown in Table1.

Table1: Influence of Capital Adequacy on Financial Performance

\begin{tabular}{|c|c|c|c|c|c|}
\hline & $\mathbf{N}$ & Min & Max & Mean & Std.Dev. \\
\hline Our bank had a high capital adequacy ratio for the last 5 years & 103 & 2 & 5 & 3.49 & .790 \\
\hline $\begin{array}{l}\text { Our bank ventured into bancassurance because it was inadequately } \\
\text { Capitalized and it thus sought capital infusion from bancassurance }\end{array}$ & 103 & 2 & 5 & 3.50 & .969 \\
\hline $\begin{array}{l}\text { We ventured into bancassurance because banks with higher levels of } \\
\text { Capital tend to perform better than their under capitalized peers }\end{array}$ & 103 & 2 & 5 & 3.76 & .902 \\
\hline $\begin{array}{l}\text { Our bank tookup bancassurance since adequate capital provides the } \\
\text { Ultimate protection against in solvency and liquidation arising from the } \\
\text { risk in banking business }\end{array}$ & 103 & 2 & 5 & 3.89 & .740 \\
\hline $\begin{array}{l}\text { Higher capital levels arising from bancassurance has enhanced our risk } \\
\text { Mitigation process }\end{array}$ & 103 & 2 & 5 & 3.96 & .766 \\
\hline $\begin{array}{l}\text { Higher capital levels arising from bancassurance has enhanced our } \\
\text { customer product portfolio }\end{array}$ & 103 & 1 & 5 & 3.99 & .693 \\
\hline $\begin{array}{l}\text { The higherlevels of capitala rising from bancassurance has enhanced } \\
\text { Our level of financial performance }\end{array}$ & 103 & 3 & 5 & 3.97 & .296 \\
\hline
\end{tabular}

Dominant part of the respondents concurred that there the banks wandered into bancassurance since they were deficiently promoted and they consequently looked for capital mixture from bancassurance (3.50), that the banks took up bancassurance since satisfactory capital gave a definitive insurance against bankruptcy and liquidation emerging from the hazard in banking business (3.89), that they wandered into bancassurance since manages an account with more elevated amounts of capital will in general perform superior to their undercapitalized peers (3.76), that higher capital dimensions emerging from bancassurance had upgraded our hazard alleviation process (3.96), that higher

Published By:

Blue Eyes Intelligence Engineering

\& Sciences Publication

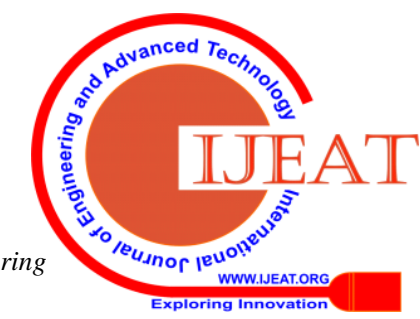


capital dimensions emerging from bancassurance had improved their client item portfolio (3.99) and that the larger (3.97). The respondents were anyway uncertain whether the banks have had a high capital sufficiency proportion throughout the previous 5 years (3.49). Besides, higher varieties in the reactions as appeared by the standard deviation esteems were seen when the respondents were asked issues managing deficiently capitalization (0.969) and keeps money with more elevated amounts of capital will in general perform superior to their undercapitalized peers (0.902).

\section{Influence of Asset Quality on Financial Performance}

The examination further tried to set up the impact of advantage quality on the monetary execution in accordance with the second investigation objective. Table 2 demonstrates the discoveries identified with resource quality and money related execution. The respondents, by and large, concurred that the banks allow advances that must be very much analyzed and in consistence to existing financial guidelines (3.52), that they wandered into bancassurance in light of the fact that their banks had a sound credit culture amounts of capital emerging from bancassurance had improved their dimension of money related execution

that is trusted by their clients (3.72), that the bank's acknowledge approaches were incorporated for execution destinations and therefore bancassurance assumed a basic job (3.86), that the bank's credit the board framework includes all offices that handle clients accordingly limiting the negative impacts of terrible obligations (4.02), that higher resource quality dimensions emerging from bancassurance in their bank had improved their client item portfolio (4.01) and that the more elevated amounts of benefit quality emerging from bancassurance had upgraded their dimension of budgetary execution (3.96). The respondents were anyway uncertain about whether the bank's proportion of net non-performing credits to the gross advances throughout the previous 5 years had been low (3.16). Besides, higher varieties in the reactions as appeared by the standard deviation esteems were seen when the respondents were asked whether the bank had a sound credit culture that is trusted by our clients (0.984).

Table2: Influence of Asset Quality on Financial Performance

\begin{tabular}{|l|l|l|l|l|}
\hline $\begin{array}{l}\text { Our bank's ratio ofnet non-performing loans to the gross loans for } \\
\text { the last 5 years has been low }\end{array}$ & Std.Dev. \\
Our bank grants loans that must be well examined and in \\
Compliance to existing banking rules \\
$\begin{array}{l}\text { We ventured into bancassurance because our bank has a } \\
\text { Sound credit culture that is trusted by our customers }\end{array}$ \\
$\begin{array}{l}\text { Our bank's credit policies are integrated with performance } \\
\text { Objectives and thus bancassurance plays a critical role }\end{array}$ \\
$\begin{array}{l}\text { The bank credit management system involves all } \\
\text { Departments that handle customers there by minimizing the } \\
\text { negative effects of baddebts }\end{array}$ \\
$\begin{array}{l}\text { Higher asset quality levels arising from bancassurance in } \\
\text { Our bank has enhanced our customer product portfolio }\end{array}$ \\
$\begin{array}{l}\text { The higher levels of asset quality arising from } \\
\text { Bancassurance has enhanced our level of financial performance }\end{array}$ & 103 & 1 & & \\
\hline
\end{tabular}

\section{Influence of Liquidity on Financial Performance}

The investigation at that point tried to set up the impact of liquidity on money related execution of banks in Bhubneswar, India. Greater part of the respondents concurred that the bank's liquidity proportion for as long as 5 years had been over the suggested proportion of $20 \%$ (3.56), that the banks regularly met their momentary commitments because of expanded liquidity emerging from bancassurance (3.85), that they wandered into bancassurance so as to raise their liquidity property and decrease liquidity dangers (4.05), that the bank's acknowledge strategies were incorporated for execution destinations and in this manner bancassurance assumed a basic job (4.10), that the bank's expanded liquidity emerging from bancassurance had upgraded their credit dispensing to clients (4.08), that higher liquidity levels emerging from bancassurance in their banks had improved their client item portfolio(4.10) and that more elevated amounts of liquidity emerging from bancassurance had improved their dimension of monetary execution (3.99). 
Table3: Influence of Liquidity on Financial Performance

\begin{tabular}{|l|l|l|l|l|l|}
\hline $\begin{array}{l}\text { Our bank's liquidity ratio for the past 5 years has been above the } \\
\text { recommended ratio of 20\% }\end{array}$ & Mean & Std.Dev. \\
Our bank often meets its short term obligations due to increased \\
Liquidity arising from bancassurance \\
We ventured into bancassurance inorder to raise our liquidity holdings \\
and reduce liquidity risks
\end{tabular}

Influence of Management Quality on Financial Performance
The study lastly sought to establish the influence of management quality on financial performance of banks. The findings are depictedin Table 4.

Table4: Influence of Management Quality on Financial Performance

\begin{tabular}{|l|l|l|l|l|l|}
\hline $\begin{array}{l}\text { Our bank's venturing into bancassurance has reduced risks in our } \\
\text { operations in the last 5 years }\end{array}$ & Min & Max & Mean & Std.Dev. \\
Our bank often offers other auxiliary services to our customers since & & & \\
venturing into bancassurance \\
Despite venturing into bancassurance our management has been \\
Able to minimize operating expenses
\end{tabular}

Larger part of the respondents were in understanding that the bank's wandering into bancassurance had diminished dangers in their tasks over the most recent 5 years (3.74), that the banks regularly offered other assistant administrations to their clients since wandering into bancassurance (3.83), that regardless of wandering into bancassurance their administration had the capacity to limit working costs (3.98), that the bank's administration guaranteed smooth everyday activities, treatment of dangers and arrangement of stewardship in bancassurance exercises (4.08), that the bank's administration objective was to amplify investor esteem through bancassurance (4.13), that more elevated amounts of the executives quality emerging from bancassurance in their banks had upgraded their client item portfolio (4.19) and that the more elevated amounts of the board quality emerging from bancassurance had improved their dimension of monetary execution (3.93). The examination completed a relapse investigation to test the hugeness of the impact of the autonomous factors on money related execution (ROA). The model rundown is portrayed in Table 5. 
Table 5: Regression Model Summary

\begin{tabular}{|l|l|l|l|l|}
\hline Model & $\mathbf{R}$ & $\mathbf{R} 2$ & AdjustedR & StdErrorOf \\
\hline ROA & 0.7851 & 0.6163 & 0.6178 & 0.4247 \\
\hline
\end{tabular}

The R2 value of 0.6163 impliesthat $61.6 \%$ of the variations in the financial performance of banks in
Bhubaneswar can be explained by the variations in independent variables. This therefore means that other factors not studied in this study contribute $39.4 \%$ of financial performance of banks in Bhubaneswar,India. The corresponding coefficients are presented in Table6.

Table 6:Multiple Regression Analysis for Return on Assets

\begin{tabular}{|c|c|c|c|c|c|c|}
\hline \multirow{2}{*}{\begin{tabular}{|l} 
Model \\
1
\end{tabular}} & & \multicolumn{2}{|c|}{ UnstandardizedCoefficients } & \multirow{2}{*}{\begin{tabular}{|l|}
$\begin{array}{l}\text { Standardized } \\
\text { Coefficients }\end{array}$ \\
B \\
\end{tabular}} & \multirow[b]{2}{*}{$\mathbf{T}$} & \multirow[b]{2}{*}{$\mathbf{P}$} \\
\hline & & B & SE & & & \\
\hline & Constant & 1.562 & 1.244 & & 2.773 & 0.271 \\
\hline & CapitalAdequacy & 0.378 & 0.142 & 0.304 & 3.432 & 0.001 \\
\hline & AssetQuality & 0.792 & 0.128 & 0.491 & 3.220 & 0.012 \\
\hline & Liquidity & 0.097 & 0.044 & 0.039 & 1.902 & 0.076 \\
\hline & $\begin{array}{l}\text { Management } \\
\text { Quality }\end{array}$ & 5.192 & 0.144 & 0.153 & 2.732 & 0.004 \\
\hline
\end{tabular}

From the different relapse demonstrate, holding capital sufficiency, resource quality, liquidity and the executives quality consistent, budgetary execution of banks would increment by 1.562 . It was set up that a unit increment in capital sufficiency would cause an expansion in money related execution by a factor of 0.378 , a unit increment in resource quality would cause an increment in monetary execution by a factor of 0.792 , a unit increment in liquidity would cause a lessening in budgetary execution by a factor of 0.097 and a unit increment in the executives quality would cause an increment in monetary execution by a factor of 5.192. The un-institutionalized beta coefficients were then used to acquire the general relationship and the model was defined as:

$$
\mathrm{Y}=1.562+0.378 \mathrm{X} 1+0.3792 \mathrm{X} 2-0.097 \mathrm{X} 3+5.192 \mathrm{X} 4
$$

Where $\mathrm{Y}=$ Financial Performance $(\mathrm{ROA}), \mathrm{X} 1=$ Capital Adequacy, X2 = Asset Quality, X3 = Liquidity, X4 = Management Quality. From the model capital sufficiency is decidedly related and factually huge to ROA. Resource Quality demonstrated a beneficial outcome to ROA of 0.792. The executives Quality was the variable found to have the best constructive outcome (5.192) on money related execution. The suggestion was that the exceedingly performing banks have the best bore of the board staff and pay their representatives well in respect to humble performing banks. In conclusion it was discovered that liquidity had a negative impact of - 0.097 however it was factually inconsequential. These can be clarified by the way that the open door cost of holding high liquidity which is portrayed by loss of a chance to clutch high enthusiasm creating ventures would show that there is an ideal point past which high liquidity has no beneficial impacts.

\section{CONCLUSIONS}

The presumed that banks wandered into bancassurance since they were insufficiently promoted and took up bancassurance since satisfactory capital gave a definitive assurance against bankruptcy and liquidation emerging from the hazard in banking business. So also, It was presumed that higher resource quality dimensions had upgraded their client item portfolio and along these lines improved their dimension of budgetary execution. The examination presumed that liquidity essentially affected money related execution of banks however the impact was negative in nature. In conclusion it was presumed that administration quality assumed a key job in upgrading money related execution of banks since they guarantee smooth everyday tasks, treatment of dangers and arrangement of stewardship.

\section{REFERENCES}

1. Abata,M.(2014).Assets Quality and Bank Performance: A Study of Commercial Banks in Nigeria. Research Journal of Finance and Accounting, 5(18),39 44.

2. Agarwal,V.(2004).Bancassurance-Concept, Framework \& Implementation, Journal of Insurance Institute ofIndia,30,34- 51 .

3. Aruwa,S.,\&Musa,A.(2014).Risk components and the financial performance of deposit money banks in Nigeria.International Journal of Social Sciences and Entrepreneurship, l(11),514-522.

4. Awino, A., Muchara,M., Ogutu,M., \& OebaL. (2012).Total Quality and Competitive Advantage of Firms in the Horticultural Industry in India, Prime Journal of Business Administration and Management, 2(4),521-532.

5. CBK(2012).CBK Bank Supervision Report, Nairobi:Government Printers.

6. Deming,W.(1995).Out of Crisis. Cambridge, Mass.: MIT Center for Advanced Engineering Study.

7. Demirgüç-Kunt, A., \& Huizinga,H. (1999). Determinants of commercial bank interest margins andprofitability: some international evidence. The World Bank Economic Review, 13(2),379-408.

8. Eriksson, H., \& Hansson, J. (2002). The impact of TQM on financial performance. Measuring Business Excellence,6(4),44-54. 
9. Goddard,J., Molyneux,P.,\& Wilson,J.(2004). The profitability of European banks:Across sectional and dynamic panel analysis. The Manchester School,72 (3),363-381.

10. Juma,S.(2015). Effect of Bancassurance on Financial Performance of Insurance Companies in India: A Survey of Insurance Companies in Nairobi County, Unpublished Thesis, United States International University-Africa, Nairobi.

11. Kamau,A.(2011).Intermediation Efficiency and Productivity of The Banking Sector In India. Interdisciplinary Journal of Research in Business, 1(9),12-26.

12. Kasper,H.,Piet,H.,\&deVries,W.(1999).Services Marketing Management: An International Perspective. West Sussex,England:JohnWiley\&Sons.

13. Kithinji,A.(2010).Credit risk management and profitability of commercial banks in India. African journal of management policy,3(7),139-257.

14. Kongiri,T.(2012).Effects of CAMEL Variables on Bank Efficiency: A Panel Analysis of Indian Commercial Banks.Unpublished MBAProject,University of Nairobi.

15. Kosmidou,K.,Tanna,S.,\&Pasiouras,F.(2005).

Determinants of profitability of domestic UK commercial banks: panel evidence from the period 1995-2002, in Money Macro and Finance(MMF)Research Group Conference,1June2005, Rethymno,Greece.

16. Kumar,M.(2006).Economics of Bancassurance. Journal of Bancassurance, 85,1-4.

17. Molyneux,P.,EdwardP.,Yener,A.,\&Santiago,C.(2007). Examining the Relationships between Capital, Risk and Efficiency in European Banking. European Financial Management, 13(1),49-70.

18. Musyoki,D.,\&Kadubo,A.,(2011).The impact of credit risk management on the financial performance in India. International Journal of Business and Public Management, 14(9),302-317.

19. Mwaniki,C.,\&Okibo,W.(2014).EffectsofTotalQualityMa nagement on Financial Performance in The Banking Sector: A CaseStudy of National Bank of India, IOSR Journal of Economics and Finance,3(2),34-40.

20. Ogilo,F.(2012).The Impact of Credit Risk Management on the Financial Performance of Commercial Banks in India. DBA Africa Management Review2012,3,22-37.

21. Olagunju,A.,David,O.,\&Samuel,O.(2012). Liquidity Management and Commercial Banks' Profitability in Nigeria. Research Journal of Finance and Accounting,2(7-8),24-38.

22. Olalekan,A.,\&Adeyinka,S.(2013).CapitalAdequacyandB anks'Profitability: An Empirical Evidence From Nigeria.American International Journal of Contemporary Research,3(10),87-93.

23. Omondi,P.(2013).Determinants of Adoption of Bancassurance by Commercial Banks in India.Unpublished MBA project, University of Nairobi.

24. Saunders,M.,\&Lewis,P.(2009).Research Methods for Business Students,(5thEd.).Harlow:PrenticeHall.

25. Shen,C.,Chen,Y.,Kao,L.\& Yeh,C.(2010).Bank liquidity risk and performance. International Monetary Fund, Working Paper.

26. Staikouras,C.,\&Wood,G., 2004. The determinants of European bank profitability. International Business and Economics Research Journal,3(6),57-68.

27. Vighneswara,S.(2015).Determinants of Assets Quality and Profitability:An empirical assessment. Available in www.ibsindia.org.

28. Voutilainen,R.(2005). Comparing alternative structures of financial alliances.The Geneva Paperson Risk and Insurance,30(2),327-42. 